\title{
A study of Pagu proverbs: Saving an endangered language of North Halmahera
}

\author{
Dalan M. Perangin-Angin ${ }^{*}$ and Novita Dewi ${ }^{2}$ \\ ${ }^{1}$ Faculty of English Letters, Sanata Dharma University, Jalan STM Pembangunan No.12, Mrican, CT Depok, \\ Sleman, Yogyakarta 55281, Indonesia \\ ${ }^{2}$ Graduate Program in English Language Studies, Sanata Dharma University, Jalan Affandi, Mrican, \\ CT Depok, Sleman, Yogyakarta 55281, Indonesia
}

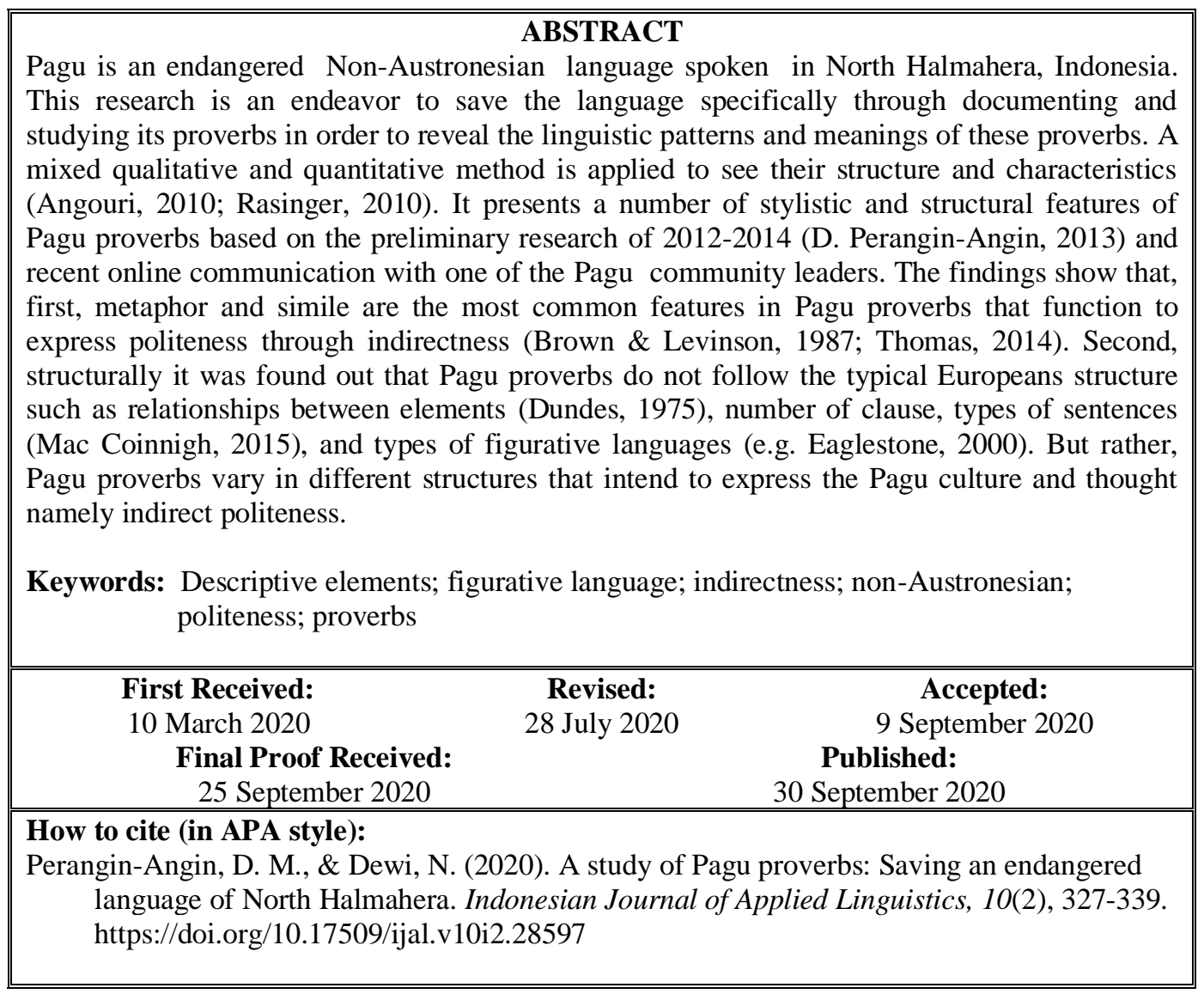

\section{INTRODUCTION}

A sizeable number of recent studies on endangered languages has shown that proverb is among the cultural-literary texts worth preserving to generate interests in the language (Michael, 2014; Njwe, 2015; Obadan, 2015; Onanuga, 2019). This study is an investigation of the Pagu language, specifically its proverbs. As one of the endangered NonAustronesian languages spoken in North Halmahera, the North Maluku Province of Indonesia, the Pagu language is worth salvaging (Hisyam et al., 2013; Lauder, 2018). While research on Pagu is limited (e.g. Perangin-Angin, 2013; Perangin-Angin, 2020;
Hisyam et al., 2012; Hisyam, et al., 2013; PeranginAngin, 2018), some specific documentation and scholarly discussion on Pagu proverbs are likewise underrepresented. Only a few collections of proverbs from regional languages in eastern Indonesia, especially in the Moluccas are available.

Following the Sapir-Whorf Hypothesis on the direct relationship among Language, Thought and Culture (Ahearn, 2011, p. 70), the present research argues that studying Pagu's thought and culture can be achieved by studying its proverbs. Language documentation is crucial because its disappearance means "an erosion or extinction of ideas, of ways of

\footnotetext{
* Corresponding Author

Email: dalan@usd.ac.id
} 
knowing, and ways of talking about the world and human experience." (Harrison, 2010, p. 7). It is unfortunate that Pagu hardly enjoys popularity among the young people. Many of them experience difficulties in expressing themselves in Pagu, to say nothing of their knowledge of proverbs in their own ancestral language.

Proverb is known as o demo ma daili in Pagu or "language of examining". To quote Foley, (1994, p. 361), "proverbs are passed on generation to generation in a quite fixed form to communicate an important moral and practical truth which pertains to a new situation". While thought may represent "important moral truth", culture represents "practical truth".

To understand the proverbs along with their moral and cultural messages, it is important to know the distribution and the structure of the proverbs. What we meant by distribution include their types of objects, i.e. they are natural to the surroundings. To illustrate, Indonesian proverbs involve 'dog' and 'cat', while in Pagu, the fighting characters are 'dog' and 'pig'.

Thought and culture can be revealed through the proverbs' distribution and structure. Boas stipulates that "the particular language spoken by a group of people merely tended to reflect their habitual cultural practices" (Ahearn, 2011, pp. 6677). This entails that they are more likely to use objects in their proverbs (metaphors) that are native to their natural surrounding such as chickens, pigs, seaweeds, coconuts. The use of metaphors and similes also reflect the people's culture of not uttering one's intention vulgarly.

It is also of great importance to investigate where the proverbs come from to see whether they are borrowed from the neighbouring communities or otherwise (Mieder, 2006, 2015). We will see that proverbs within the local distributions will share similar moral values and cultural messages but those from outside do not. The discussion will also include the objects/elements mentioned in the proverbs to understand the extent to which they have a special bond to the Pagu people.

\section{Review of Pagu an endangered language worth saving}

Pagu is a Non-Austronesian (Papuan) language that belongs to the West-Papuan language phylum (Lauder, 2018). It is spoken in the south-eastern end of the west northern peninsula of the Halmahera Island, the North Maluku province, Indonesia (see Figure 1 and 2).

\section{Figure 1}

\section{Halmahera in the Indonesian archipelago}

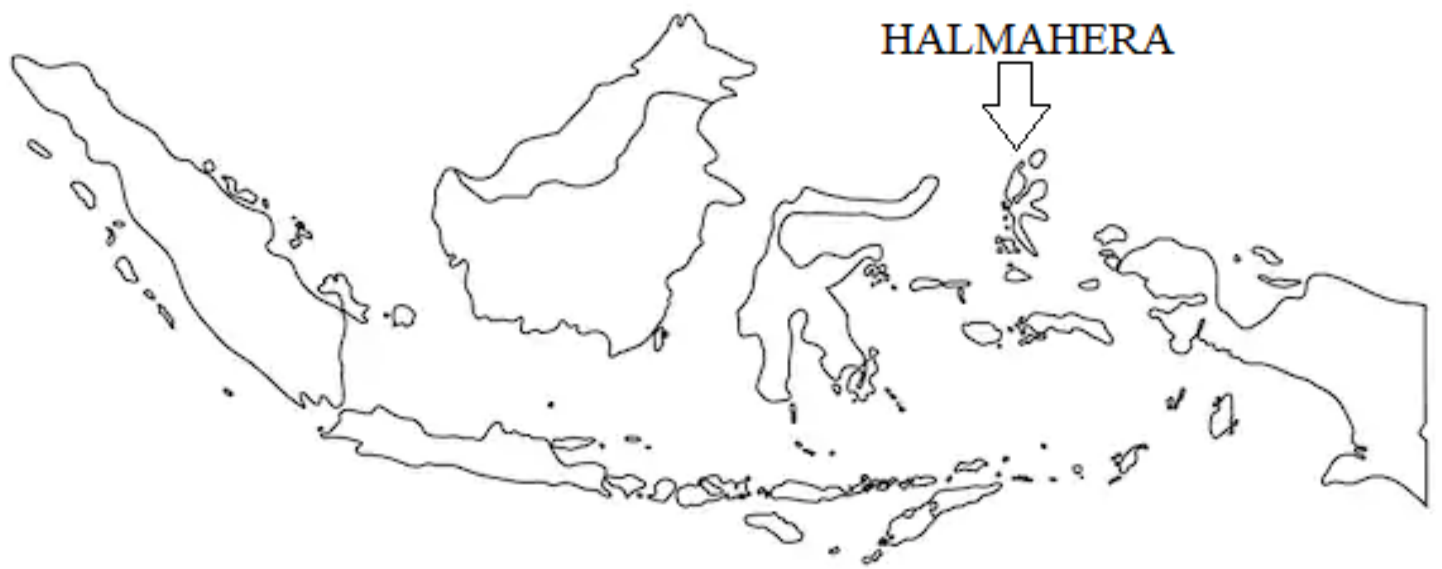

Figure 2

Halmahera map with the Pagu region shaded

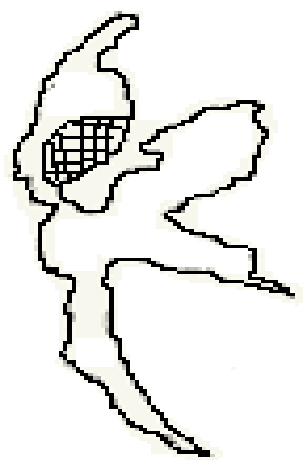


Together with Galela, Tobelo, Modole, Tabaru, Loloda, and Sahu (see Figure 3), Pagu belongs to the mainland sub-group of the Northern sub-family of the North Halmahera family, whereas Ternate and Tidore languages, spoken in the two smaller islands to the west of Halmahera, belong to the other branch of this sub-group (Voorhoeve in Perangin-Angin, 2020, p. 182). Meanwhile, West Makian is sub-grouped within the Southern subfamily (Voorhoeve, 1988).

\section{Figure 3}

Pagu as a Member of the North Halmaheran Family (Voorhoeve, 1984, p. 19).

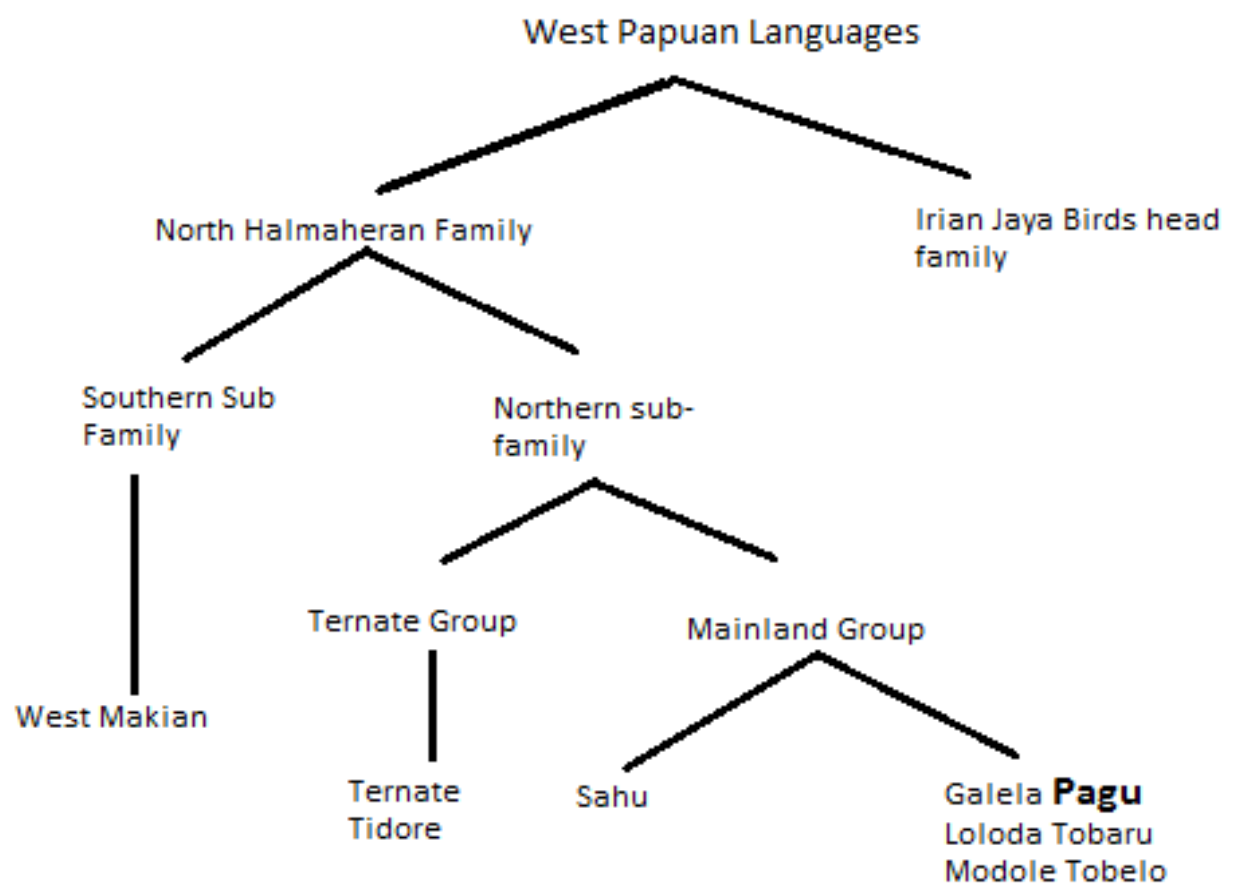

Pagu is spoken by just half of its total 5,500 people by the 2012 population census. Pagu is mostly used by elders or people older than 40 years old. The youngest speakers are roughly twenty-five years old. Language transfer hardly occurs for parents commonly use Local Malay (LM) to their children (Perangin-Angin, 2020; Perangin-Angin, 2018).

According to Pigaffeta, a crew member on Ferdinand Magellan's voyage to the Maluku Islands, Malay was used in the region since the 16th century (Nowell, 2018). Because of this long language contact, the data show that Pagu and LM proverbs share some similarities, i.e. Pagu borrowed LM proverbs.

\section{METHOD}

This study applied a mixed qualitative and quantitative approach in the sense that the former focus on seeing the structure as well as ethnography of the proverbs and the latter the amount of the proverbs that share similar features (Angouri, 2010; Rasinger, 2010)

The data were collected in two different occasions. The first data consists of twenty-three proverbs that were collected during the LIPI project $(2012$ - 2014). The proverbs are all pronounced by three different native speakers (Afrida Ngato, 43 years old, the Pagu community leader; Samuel Woyo, 55, a village head of Gayok village; and Abner Soboli, aged 40, a youth leader from Gayok village). They were all recorded in a highly quality wav formatted recorder, transcribed, and translated into three languages - the LM, Indonesian and English. In addition to their meanings and figurative language (i.e. metaphors and similes), the native speakers were also interviewed concerning proverbs' history and distribution.

The second data were collected from Ms. Afrida Ngato the leader of Pagu community via emails, phone calls, and Whatsapp chats, from January to mid-February 2020. We worked with Ms Ngato only in this step because of her quality as a leader, knowledge, and also her ability in using those applications/gadgets. These data have also been transcribed and translated into the three languages including notations on their history and distribution as well. To date, the collected proverbs amount to twenty-eight. This scarce number of data results from the lack of uses in the daily lives. Speakers required more time to recall them or ask some older people.

The proverbs were first translated into LM and Indonesian with the help of Ms. Ngato. Secondly, the glossary of each of the words in the proverbs 
was made, i.e. the grammatical function of each morpheme and literal meaning of each word. The English translation was completed afterward.

\section{FINDINGS AND DISCUSSION}

Understanding Pagu proverbs will help demonstrate the morality and culture of the Pagu people by way of identifying the distribution and the structure of the proverbs. metaphor or comparison. Proverbs (1) and (2) exemplify this.

In proverb (1), the noun wola 'house' and sininga 'heart' are being compared. This shows that in the Pagu people's standard morality and culture,

$\begin{array}{ll}\text { ai wola i-tiila } & \text { ma } \\ \text { 1SPOSS house NHS-bad } & \text { but }\end{array}$

Eng: 'My house is bad but my heart is not'

Mes: 'It is personality, not the material that matters.'

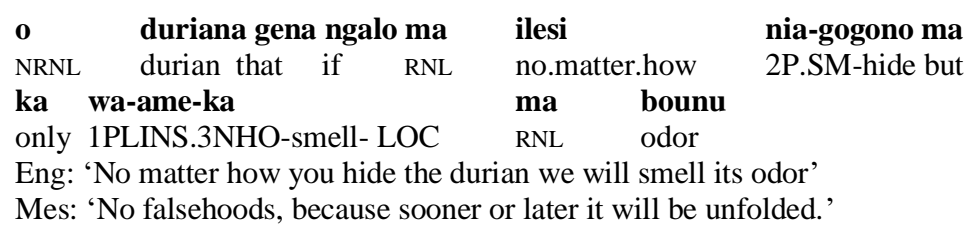

\section{Pagu proverbs distribution}

Albeit known by many people, no one really knows who said a proverb for the first time (Mieder \& Mieder, 2019, p. 9). Many proverbs have been in use for many years and continue to be used to date such as 'every man is his own worst enemy'(Manser, 2007, p. x). It is thus very difficult to tell the origin of Pagu proverbs. From the interviews, it was found that there are three 'a bad house' is less important than 'a bad heart'. Its moral messages focus on good personalities. In addition, in proverb (2), 'durian' is a very common fruit in the region and its odor is extremely strong. It represents their wicked deeds.

In order to understand further the collected proverbs, it is important to analyze the distribution, i.e. how they become Pagu Proverbs (section 1); their objects, types of objects that appear in the proverbs (section 2); and its structure, including relationships between their descriptive elements, their figurative language, their types, and the structure of the clause (section 3 ).

$\begin{array}{lc}\text { ai-sininga } & \text { i-tiila-wa } \\ \text { 1SPOSS-heart } & \text { NH.S-bad-NEG }\end{array}$

$\begin{array}{llll}\text { soka wa-damaa } & \text { siadono o } & \text { namo } & \text { i-ma-osisi } \\ \text { like 1PL.3NHO-wait } & \text { until NRNL } & \text { chicken } & \text { 3NH-REFL-urinate } \\ \text { Eng: 'like waiting for a chicken peeing' } & \\ \text { Mes: 'waiting for something that certainly will not happen' } & \end{array}$

In fact, the above proverb was once heard over in the researcher's journey in a public transportation when one passenger responded to others who were talking about promises of the then local politicians. The proverb was uttered to express their disappointment, hence hyperbolic tone is obvious in the proverb rather than metaphorical meaning (Carston \& Wearing, 2015). According to our informants, similar proverbs are also found in the neighboring languages in North Halmahera such as Tobelo, Galela, Modole, Tabaru, etc. There are two possible hypotheses of the distribution of the proverbs in languages of the region with regards to their similarities with the LM proverbs. Firstly, because LM is the region's lingua franca, speakers of the different languages acquired the proverbs and began to use them in their own languages. Secondly, as speculated (Voorhoeve, 1984, p. 19), the six regional languages, i.e. Pagu, Tobelo, Galela, Modole, Tabaru, and Loloda were once one languages that contribute to the distribution of Pagu proverbs, i.e. LM, Indonesian, and European languages (such as Dutch and/or English). According to our informants, almost all the collected proverbs have the LM version. For example, the Malay says: Sperti tunggu ayam bakincing [like waiting for a chicken peeing]. The very same meaning of proverb also exists in Pagu as follows.

language given their lexical and grammatical clossness. The proverbs formerly appeared in those languages and spread via LM.

The Pagu proverbs also have a distribution from the Indonesian proverbs (see Table 1). There are five samples from our data. Three proverbs in the table below exemplify them. Each of the Pagu proverbs above has its Indonesian version with exactly the same message (see those on the right). They also share similar elements 'oil and water' (4), 'rain and umbrella' (5), and 'thief and acknowledging' (6). However, although they may share the same elements some also differ in the sentence structure as exemplified by (6), i.e. the Pagu proverb is in a question but the Indonesian version is in an affirmative sentence.

The last distribution is from Dutch or English (European languages). One proverb belongs to this category as shown in (7). 
Table 1

Same Moral Message of Pagu and Indonesian Proverbs

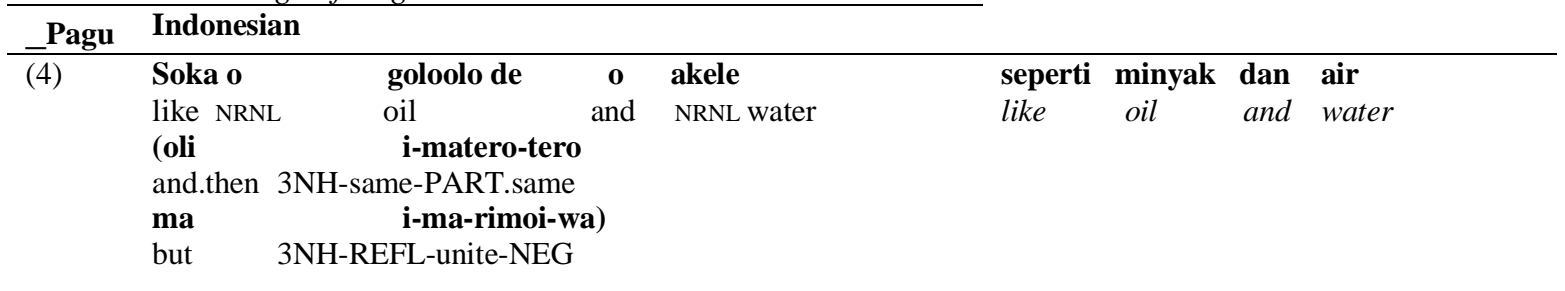

Eng: like oil and water, they never can unite

Mes:'two things that can never be together'

(5)

$\begin{array}{ll}\text { i-besaka-wasi } & \text { ena } \quad \text { ani } \\ \text { 3NH-rain-not.yet } & \text { exist } \quad \text { 2SGPoss } \\ \text { dadamunu } & \text { no-ma-degee-kau } \\ \text { umbrella } & \text { 2SG-REFL-take-certain }\end{array}$

Eng: before it rains take an umbrella first

Mes: 'be prepared in advance for any possible trouble'

(6)

$\begin{array}{ll}\text { o } & \text { nyawa yo-toli-toliki de } \\ \text { NRNL } & \text { person 3PL-PART.steal-steal and } \\ \text { ma } & \text { yo-ma-singasu la? } \\ \text { but } & \text { 3PL-REFL-tell LA }\end{array}$

sedia payung sebelum turun

hujan

prepare umbrella before go.down rain

Eng: someone stole something and then acknowledged it?

Mes: 'people always hide their bad deeds.'

$\begin{array}{llll}\text { (7) } & \text { o } \quad \text { orasa gena } & \text { la } \quad \text { o } & \text { pipi } \\ \text { NRNL time that be } & \text { NRNL money } & \\ \text { 'time is money'. } & & \end{array}$

In English or Dutch, "time is money" or "tijd is geld", respectively, are used to express how people treasure time as valuable as money. Indeed, for European people, the proverbs have practical truth and important morality in their daily live, i.e. to manage time well and be punctual. The English proverb was mentioned for the first time in 1748 by Benjamin Franklin in his Advice to a Young Tradesman although such virtue had been expressed by the earlier origin (Manser, 2007, p. 274). Given that from our observation there is no such thing as time management in the Pagu community, it is safe to say that this proverb is not strictly a Pagu proverb since it does not reflect its practical truth.

\section{Objects in Pagu proverbs}

As can be seen in examples (4) to (6), Pagu and Indonesian proverbs share the same objects to express certain moral messages. However, several proverbs in Pagu share the same messages but expressed in different objects, for example these two proverbs in the Table 2 .

Table 2

Pagu and Indonesian proverbs sharing the same moral message with different elements

\begin{tabular}{llll}
\hline Pagu & Indonesian & & \multicolumn{2}{c}{ seperti menanti kucing bertanduk } \\
\hline (8) & soka wa-damaa & siadono & like wait cat have.horn \\
& like 1PL.3NHO-wait & until & Eng. like waiting for a cat to have a horn \\
NRNL chicken & i-ma-osisi & \\
& Eng.: like waiting for a chicken peeing & \\
Mes: 'waiting for something that certainly will not happen' & \\
(9) & Matero ka o kaso de o ode. & seperti anjing dan kucing \\
like $\quad$ only NRN dog and NRNL pig & Eng: like dog and cat \\
& & \\
Eng: like a dog and a pig & & \\
Mes: 'referring to two people who never could go along well together.'
\end{tabular}


In (8) and (9) above, both Pagu and Indonesian proverbs have the same messages. However, the involving objects are not the same, i.e. in (8) we have 'chicken and peeing' versus 'chicken and having a horn', whereas in (9) we have 'dog and pig' versus 'dog and cat' in Pagu and Indonesian respectively.

What can be learned from the proverbs in Pagu and Indonesian is that the elements are more appropriate to express through metaphor in each language. Indeed, only common elements in the language that can make metaphor meaningful. Pagu proverbs thus use objects familiar to the people and normally found in their natural surroundings. It is worth noting that proverb (8) has an English equivalent - "If a pig had wings, it might fly" (Manser, 2007, p. 404).

Out of the twenty-eight proverbs, fifteen Pagu proverbs mention different types of objects that can be classified as: (i) objects from the natural surroundings, (ii) abstract/untouchable nouns, (iii) made/processed by human, and (iv) human/body parts. Table 3 below shows elements of the four different types of objects.

Table 3

Four Types of Objects in Pagu Proverbs

\begin{tabular}{|c|c|}
\hline Types of object & Nouns \\
\hline $\begin{array}{l}\text { Natural surrounding } \\
\text { objects }\end{array}$ & $\begin{array}{l}\text { 'chicken' } \\
\text { 'durian' } \\
\text { 'seaweed' } \\
\text { 'waves and shores' } \\
\text { 'birds and fruits' } \\
\text { 'beehives' } \\
\text { 'crab holes' } \\
\text { 'fire/ember' } \\
\text { 'birds' } \\
\text { 'crab and shrimp' } \\
\text { 'dog and pig' } \\
\text { 'jackfruit' } \\
\text { 'stone' } \\
\text { 'worm' } \\
\text { 'cat' } \\
\text { 'body of water' }\end{array}$ \\
\hline $\begin{array}{l}\text { Abstract/untouchable } \\
\text { nouns }\end{array}$ & $\begin{array}{l}\text { 'rain' } \\
\text { 'time' } \\
\text { 'dark and light' }\end{array}$ \\
\hline $\begin{array}{l}\text { Made/processed by } \\
\text { human }\end{array}$ & $\begin{array}{l}\text { 'oil' } \\
\text { 'house' } \\
\text { 'wall and pole' } \\
\text { 'scissors' }\end{array}$ \\
\hline Human/body parts & $\begin{array}{l}\text { 'people/human' } \\
\text { 'heart' } \\
\text { 'knee' }\end{array}$ \\
\hline
\end{tabular}

There are thirty-three different objects. The object 'chicken' appears in three proverbs, 'crab' two, 'time' two and 'house' two. Each of the other twenty-nine objects appears only in one proverb.

\section{The structure of Pagu proverbs}

Paremiology (from Greek paroimia which means proverb/maxim) is the study of proverbs. It mainly focuses on the structure of proverbs. Alan Dundes (1934-2005) was what Mieder claimed as "one of the giants of international folkloristic whose voluminous publications and lectures delivered around the world touched thousands of scholars and students of folklore" (Mieder, 2006, p. 3). In light of Dundes' insights, the present study limits itself to the structure based on three classifications: (1) relationship between elements, (2) figurative language, and (3) functions of clause (affirmative, interrogative and negative) including their clause structure.

\section{Relationships between descriptive elements}

There are two types of structure based on Dundes' classification: (1) topic-comment structure and (2) oppositional versus non-oppositional structure (Dundes, 1975). The first structure consists of one descriptive element: consisting of one topic and one comment. In 'money talks', for instance, the topic is 'money', and 'talk' is the comment. The second one consists of two descriptive elements, whose relationships can be either oppositional like in 'man proposes but God disposes' or non-oppositional such as 'where there's a will, there's a way'.

There is one among the collected proverbs that falls into the first structure shown in (7) above $o$ oras gena la o pipi 'time is money', where o orasa 'time' is the topic and o pipi 'money' is the comment. This is the only proverb of this structure. It is not surprising because this proverb is most likely borrowed from the European languages without having a practical truth among the community in question.

Among the collected proverbs there are six proverbs that can be categorized to having two descriptive elements and their relationship is all oppositional (there is no non-oppositional relationships). The six are proverbs (10), (11), (12), (13), (14) and (15).

What proverbs with oppositional relationship have in common is that there is a contrasting conjunction that relates the two descriptive elements, i.e. $m a$ 'but' like in (10), (12), (13), (14), and (15) or ngalo 'although' (11).

Mieder (2015) and Norrick (2011) also propose based on types of relationships between elements Variable $\mathrm{X}$ and $\mathrm{Y}$ structure. The variable $\mathrm{X}$ and $\mathrm{Y}$ can be formulated into several forms; some of them are shown below. None of the Pagu proverbs however have these relationships:

a. Better $\mathbf{X}$ than $\mathbf{Y}$, for example: "better poor with honor than rich with shame" 
b. Like X, like $\mathbf{Y}$, for example: "like father like son"

c. No X, without $\mathbf{Y}$, for example, "no work, no pay"

d. One X doesn't make a Y, for example: "one swallow doesn't make a summer"

e. If $\mathbf{X}$ then $\mathbf{Y}$, for example: "if at first you don't succeed then try, try again"

\section{Figurative language}

Types of figurative language include simile, metaphor, personification, hyperbole, allusion, irony, sarcasm, symbolism, etc. (e.g. Citron \& Zervos, 2018; Cuddon, 2012; Eaglestone, 2000; Gibbs Jr \& Colston, 2012; Glucksberg, 2008). Pagu proverbs can be classified into two main types only, namely, simile and metaphor.

Simile is a figurative language that makes a comparison, showing similarities between two different things. It draws resemblance using the words "like" or "as." Therefore, it is a direct comparison (Cuddon, 2012, p. 240; Eaglestone, 2000, p. 105). Meanwhile, metaphor is a figure of speech that makes an implicit, implied, or hidden comparison between two things that are unrelated, but which share some common characteristics (Cuddon, 2012, p. 146; Eaglestone, 2000 , p. 110). In other words, unlike similes, metaphors present the resemblance of two contradictory or different objects.

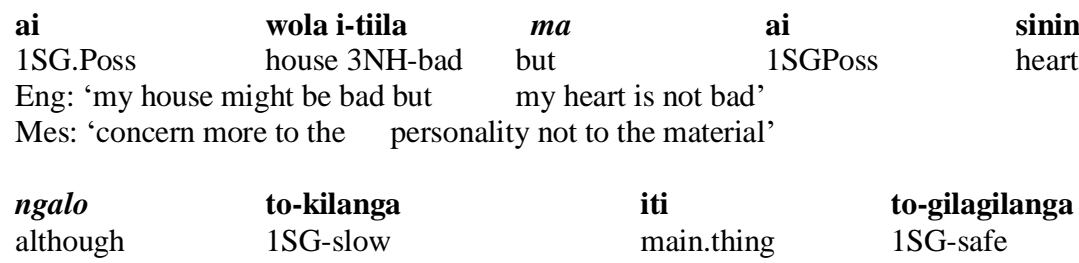

Eng: 'although I am slow the main thing is I am safe'

Mes: 'concern more on oneself safety'.

\begin{tabular}{|c|c|c|c|c|}
\hline ngalo & mia-wola & i-peeto & $m a$ & mia- \\
\hline although & 1PLEXposs- house & 3NH-narrow & but & 1PLEXposs \\
\hline sininga & i-peeto-wa. & & & \\
\hline heart & 3NH-narrow-NEG & & & \\
\hline \multicolumn{5}{|c|}{ Eng: 'my house might be narrow, but my heart is not narrow' } \\
\hline Mes:"con & personalit & the materials' & & \\
\hline
\end{tabular}

(13)

wo-tibako o bebeno-ka $\quad$ ma wo-ma-si-tolo
3PL-throw wath wall-to
o ngasuk-ika.
NRNL pole-DAS
Eng: 'throw something to the wall but it hit the pole instead'
Mes: 'criticizing someone but actually it fitted with him/herself.'

$\begin{array}{llllll}\text { ma tuada } & \text { ma lakeme } & \text { o } & \text { nyawa } & \text { ya-oyomo } & \text { ma } \\ \text { RNL jackfruit } & \text { RNL flesh } & \text { NRNL person } & \text { 3PL.3NHO-eat } & \text { but } \\ \text { titigon } & \text { ngone } & \text { wa-make. } & & \\ \text { sap } & \text { 1PL.IN } & \text { 1PL.IN.3NHO-meet } & \end{array}$

Eng: 'someone else ate a jackfruit but we got its sap'

Mes: 'someone enjoyed doing something, but other people underwent its bad consequences.'

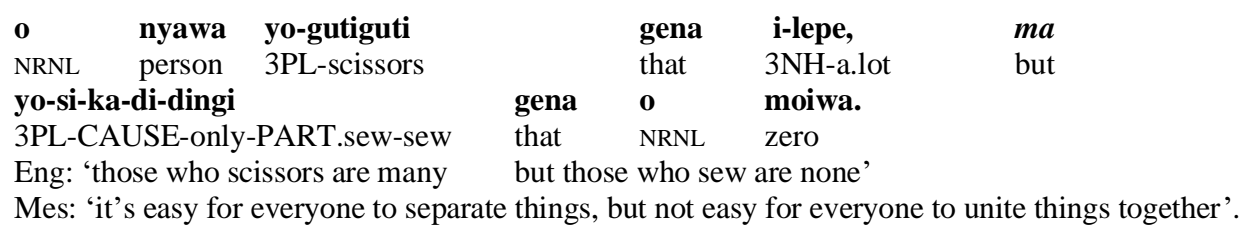

There are thirteen proverbs that can be categorized as similes. They are marked by the preposition soka (nine proverbs) or matero (four) that both mean 'like' or 'as'. The word soka always occurs in the beginning of the proverbs as exemplified by (16) and (17) below. Its function is to compare the nature of the object/activity mentioned in the clause(s). Please see the literal (lit.) translation of each.

\section{o namo i-ma-osisi}

NRNL chicken 3NH-REFL-urinate

like 1PL.3NHO-wait

Mes: 'waiting for something that certainly will not happen' 


$\begin{array}{lll}\text { soka } & \text { o } & \text { uku ma ngabos- } \\ \text { like } & \text { NRNL } & \text { fire poss ember- }\end{array}$

Eng. 'it's like stepping on embers

Mes: 'referring to someone who is very busy that s/he doing things in rush'

The word matero on the contrary, always occurs in the middle of the proverbs. It functions to connect two situations as exemplified by proverb (18) and (19). The first situation in (18) is 'a crab advises a shrimp but then both got burned' and the second is 'both turned red (their skin)'. Matero connects the two situations as a simile yielding that the second one resembles the nature of the second. The same thing happens in (19). The first situation is 'an older and younger brother fight each other' and the second one 'the relationship between a dog and a pig' (they never get along very well).

$\begin{array}{lll}\text { o kakaelasa } & \text { de } & \text { i- } \\ \text { NRNL crab } & & \text { and } 3 \mathrm{NH}- \\ \text { wa-kumumu } & & \text { matero bato } \\ \text { 1PL.3NHO-burn } & \text { like } & \text { only }\end{array}$

Eng: 'a crab wanted to advise a shrimp, but when burned both

temo $\quad$ o
talk $\quad$ dodeka
i-ma-si-du-kuulung-
3NH-REFL-CAUSE-BEN-red-
$\quad$ turned red

to each other'

\begin{tabular}{|c|c|c|c|c|}
\hline o liaka & de & o & & $\begin{array}{l}\text { dodoto de yo-maka-gewisi } \\
\text { younger.sibling and 2PL-MUT-bite }\end{array}$ \\
\hline $\begin{array}{l}\text { NRNL } \\
\text { matero }\end{array}$ & older.sibling and & NRNL & & younger.sibling and 2PL-MUT-bite \\
\hline $\begin{array}{l}\text { matero } \\
\text { like }\end{array}$ & $\begin{array}{ll}\text { Ka } & \mathbf{0} \\
\text { only } & \text { NRNL }\end{array}$ & $\begin{array}{l}\text { Kaso } \\
\text { dog }\end{array}$ & $\begin{array}{l}\text { de } \\
\text { and }\end{array}$ & $\begin{array}{ll}\text { o } & \text { ode. } \\
\text { NRNL } & \text { pig }\end{array}$ \\
\hline
\end{tabular}

The first situation is normally an affirmative clause like in (18) and (19). However, there is also a proverb with matero whose first situation is a question like (20).

Next, there are ten metaphors, comparisons that make use of neither matero nor soka as a 'linker'. The situation mentioned in the proverb functions to figure out a comparison in the real life that will act as a reminder for listeners to behave wisely. This is exemplified by (21) and (22). In (21) the mentioned situation about the nature of durian (that its odor cannot be hidden) becomes the metaphor (comparison) to remind people not to hide bad deeds. Additionally, the situation of preparing an umbrella before rain in (22) is also the metaphor conveying message to preparing something in advance to avoid bad consequences.

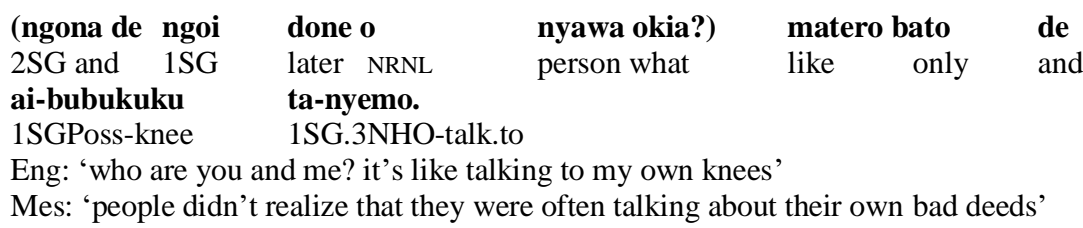

\begin{tabular}{|c|c|c|c|c|}
\hline o duriana & gena ngalo & maile-si & nia-gogono & ma \\
\hline . & durian & that & a.few-still & 2PL-hide but \\
\hline & wa-ame-ka & & bounu & \\
\hline only & 3PLIN.3NHC & 11-to & odor & \\
\hline
\end{tabular}

Eng: 'no matter how small you hide a durian, someone will surely sniff its odor'

Mes: 'you cannot hide a bad deed however small it is, coz soon or later someone else will discover it'

i-besaka-wasi ena ani -dadamunu
3NH-rain-not.yet exist
Eng: 'before it rains take an umbrella first'
Mes: 'be prepared in advance'

no-ma-degee-kau. 2SG-REFL-take-certain

\section{Types of clause: number of clauses}

According to Mac Coinnigh (2015), crosslinguistically, the sentence types of proverbs can be divided into four: simple (one clause), compound (two clauses with a coordinator) complex (one main clause and at least one sub clause) and compound complex (at least two main clauses and one sub clause). Among these patterns, the one-clause proverbs (one main clause without a subclause) are the most common.

By comparison, in Pagu, morphologically, the predicates can be classified into two types: (1) unmarked or (2) marked, where the predicate is attached by a pronoun prefix that agrees with the gender, number, animacy, and exclusivity of the subject (Perangin-Angin, 2018). 
What follows are the Pagu morphological distinctions of marked/unmarked predicate of each clause of the proverbs. The most common type of predicate/clause is the marked ones, except three proverbs. The two proverbs below exemplify the marked ones.
(23)

$\begin{array}{ll}\text { soka wa-damaa } & \text { siadono } \\ \text { like } 1 \text { PL.3NHO-wait } & \text { until }\end{array}$

Eng: 'like waiting for a kitchen peeing

Mes: 'waiting for something that certainly will not happen'

$\begin{array}{llll}\begin{array}{l}\text { ngalo } \\ \text { although }\end{array} & \frac{\text { to-kilanga }}{1 S G-s l o w} & \text { iti } & \text { to-gilagilanga } \\ \text { main.thing } & \frac{\text { L }}{\text { 1SG-safe }}\end{array}$

Eng: although I am slow the main thing is I am safe'

Mes: 'concern more on oneself safety'.

In (23) there are two predicates damaa 'wait' and ma-osisi 'have urinating'. Each is attached by a pronoun prefix, i.e. the former by $w a$ - that agrees with both the subject 'we' (plural first person) and the object 'a chicken' (non-human object), and the latter by $i$ - that agrees with the subject 'a chicken' (non-human subject). Note that in the marked predicates, the pronoun prefix occurrence is compulsory. It must refer to the subject (or also the object) of the predicate. The subject pronoun (to where the pronoun prefix refers) is not compulsory however. In this example, the subject argument of the pronoun prefix $w a$ - does not appear, but the subject of the pronoun prefix $i$ - appears namely $o$ namo 'chicken' ( $i$ - refers to it). Because of these occurrences of the two predicates and their pronoun prefixes, this proverb can be said to have two clauses.

In proverb (24), there are also two predicates kilanga 'slow' and gilagilanga 'safe'; each of them is attached by pronoun prefix to- that agrees with the subject 'I'. Because of the same reason, this proverb also consists of two clauses.

There are only three unmarked predicates in our collected proverbs, i.e. (25), (26) and (27).

$\begin{array}{llllll}\text { o } & \text { orasa } & \text { gena } & \text { la } & \text { o } & \text { pipi } \\ \text { NRNL } & \text { time } & \text { that } & \text { be } & \text { NRNL } & \text { money } \\ \text { 'time is money' } & & & & \end{array}$

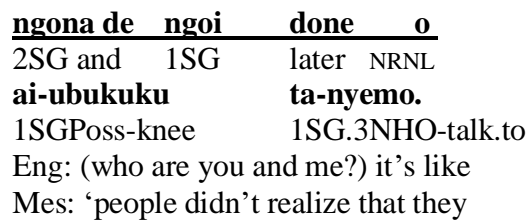

nyawa okia? person what

$\begin{array}{ll}\text { matero bato de } & \text { de } \\ \text { like only and }\end{array}$

talking to my own knees)

were often talking about their own bad deeds'

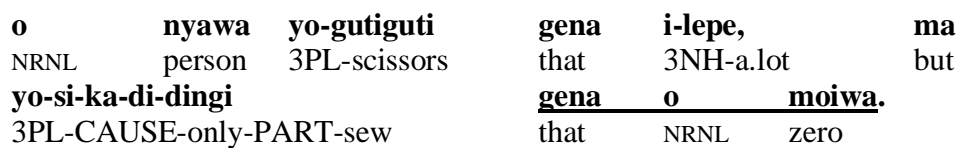

Eng: 'those who scissors are many but those who sew are none'

Mes: 'it's easy for everyone to separate things, but not easy for everyone to unite things together'.

In (25) above, there is no predicate. Rather, there are two noun phrases o orasa 'the time' and $o$ pipi 'money'. The second one modifies the first, i.e. 'money' shares the same value with 'time'. The second one is called Predicate Nominal because the 'predicate' is a noun (Payne, 2007). In the first clause of (26) the predicate is also unmarked (the underlined). It is a nominal predicate o nyawa okia 'what people' that modifies the subject ngona de ngoi 'you and I'. And in (27) o moiwa 'zero' also is unmarked (nominal predicate) that modifies gena 'that'.

Based on the definition of 'clause' whether marked or unmarked, this research classifies the number of clauses of each proverb as outlined in Table 4.
Table 4

\begin{tabular}{|c|c|}
\hline Number of clauses & Total number \\
\hline 1 clause & 5 \\
\hline 2 clauses & 18 \\
\hline 3 clauses & 2 \\
\hline 4 clauses & 2 \\
\hline 5 clauses & 1 \\
\hline
\end{tabular}

The most common ones are those with two clauses (there are eighteen proverbs) and least common ones are three-clause, four-clause and fiveclause proverbs that only have two, two, and one sample respectively. The second most common is one-clause proverb with nine samples.

The proverbs with more than one clause can also be categorized to be complex and compound 
types (there is no compound-complex type). There are nineteen numbers of complex sentences and four compound sentences. Table 5 below shows the proverbs that fall into the three sentences types.

Table 5

Pagu Proverbs with Different Sentence Types

\begin{tabular}{lc}
\hline Sentence type & Total number \\
\hline Simple sentence & 5 \\
Complex sentence & 17 \\
Compound sentence & 6 \\
\hline
\end{tabular}

Unlike that of Mac Coinnigh (2015), the most common proverbs in Pagu are not simple sentences rather complex sentences. This is because of the structure of the proverbs that most of them are comparisons (either similes or metaphors). They describe them by providing a situation first that is followed by one or more situations. This is exemplified by (22) and (23) above. In (22) the first situation ('it's not yet raining') is followed by the second situation ('take your umbrella already') and in (22), the first situation ('we wait') is also followed by the second one ('until a chicken pees'). Each of the situation consists of at least one clause and the second one explains about the first one.

\section{Functions of clause}

Mac Coinnigh (2015) also suggests that there are four different functions of proverbs in the world: declarative (indicative), interrogative, imperative, and exclamatory. He claims that among them the most common proverbs cross-linguistically is (affirmative) declarative such as bad news travel fast. Based on our data, affirmative declarative is the most common proverbs too; a few interrogatives; imperatives are only in negative forms; and there is no exclamatory. Other than the four functions, Pagu proverbs can also be categorized as contrastive, i.e. if one clause is positive the other one is negative. There are five contrastive proverbs among our data. The (28) and (29) proverbs exemplify this type.

28)

\begin{tabular}{lllll} 
soka & o & goloolo & de & o \\
like & NRNL & oil & and & NRNL \\
ma & i-ma-rimoi-wa. & & \\
but & \multicolumn{3}{l}{ 3NH-REFL-unite-NEG }
\end{tabular}

akele oli i-matero-tero

water then $3 \mathrm{NH}$-same-PART.same

Eng: 'like oil and water, they never can be united'

Mes: 'two things/people that can never be together'

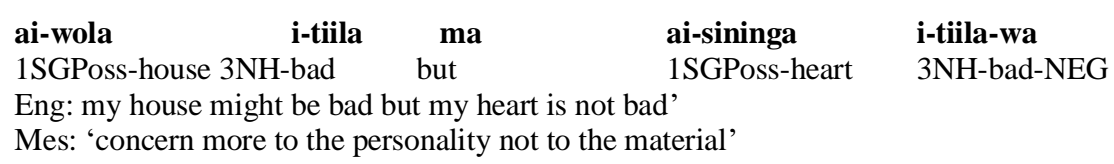

Both (28) and (29) are contrastive, where the first clause is a positive and the second one is a negative clause. The predicate of the second clause is negated by suffix -wa (NEG). Interrogative sentences only occur twice as seen in (30) and (31).

o nyawa yo-toli-toliki de ma yo-ma-singasu la?

person 3PL-PART-steal and but 3

Eng: 'someone stole something and then acknowledged it?'

Mes: 'people always hide their bad deeds.'

$\begin{aligned} & \text { ngona de } \\ & \text { 2SG and } \\ & \text { ta-nyemo }\end{aligned}$
1SG.3NHO-talk.to

In (30) the whole proverb is in a question, i.e. 'how possible is for a stealer to acknowledge his/her deed?' However, in (31), only one of the clauses is an interrogative i.e. 'who are we?' The other clause in the proverb is the metaphor that states 'we are just like people who talk to our own knee'. There are also two samples of imperative negatives (32) and (33).

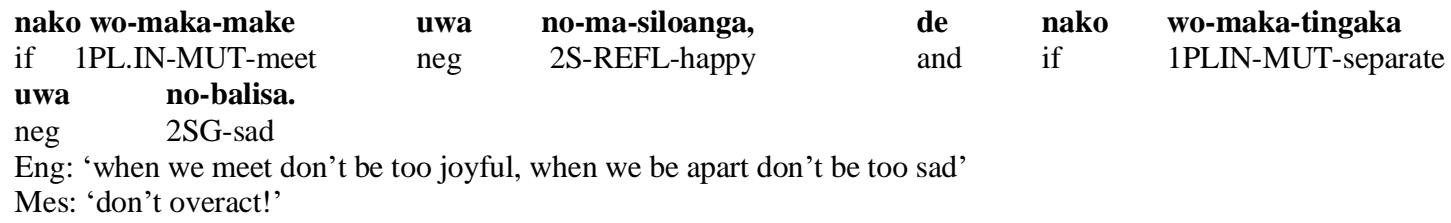


(33)

\begin{tabular}{|c|c|c|}
\hline $\mathbf{0}$ & akele & uwa \\
\hline NRNL & $3 \mathrm{NH}$-quiet & NEG \\
\hline
\end{tabular}

Both (32) and (33) are imperative negatives. Each uses the negator $u w a$, i.e. to ask to not do what stated by the predicate. Affirmative clauses are the most common types of clause among the Pagu

\author{
nio-mangitu \\ 2PL-think \\ i-luku-wa. \\ 3NH-deep-NEG
}

Table 6

Pagu Proverbs in Four Different Classifications

\begin{tabular}{|c|c|c|c|c|c|c|c|c|c|c|c|c|c|c|c|c|}
\hline \multicolumn{5}{|c|}{$\begin{array}{c}\text { Types and relationship between } \\
\text { elements }\end{array}$} & \multicolumn{3}{|c|}{ Types of figurative } & \multicolumn{4}{|c|}{ Functions of sentence } & \multicolumn{5}{|c|}{ Number of clause } \\
\hline \multirow{2}{*}{ 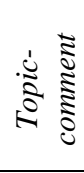 } & \multicolumn{2}{|c|}{$\begin{array}{l}\text { Oppositional } \\
\text { vs. non- } \\
\text { oppostional }\end{array}$} & \multirow{2}{*}{ 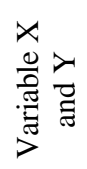 } & \multirow[t]{2}{*}{$\frac{\tilde{\Xi}}{\tilde{D}}$} & \multirow[t]{2}{*}{$\begin{array}{l}\stackrel{0}{\vec{\Xi}} \\
\stackrel{n}{n}\end{array}$} & \multirow{2}{*}{ 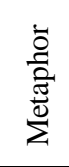 } & \multirow[t]{2}{*}{$\frac{\infty}{\vec{\Xi}}$} & \multirow{2}{*}{ 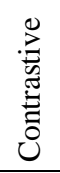 } & \multirow{2}{*}{ 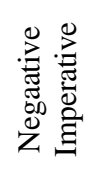 } & \multirow{2}{*}{ 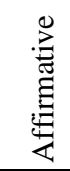 } & \multirow{2}{*}{ 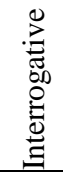 } & \multirow[t]{2}{*}{1} & \multirow[t]{2}{*}{2} & \multirow[t]{2}{*}{3} & \multirow[t]{2}{*}{4} & \multirow[t]{2}{*}{5} \\
\hline & opp. & Non. & & & & & & & & & & & & & & \\
\hline 1 & 6 & 0 & 0 & 21 & 13 & 10 & 5 & 5 & 2 & 19 & 2 & 5 & 18 & 2 & 2 & 1 \\
\hline
\end{tabular}

The three types of relationships between elements are not so common among Pagu proverbs. Most of the proverbs (twenty-one out of twentyeight) cannot be categorized into any of them. Instead, they indicate themselves to be either similes or metaphors (only five that do not fall into the two categories). This is the crux of our argument that Pagu proverbs mainly function as 'the language of examining/criticizing (the literal meaning of proverbs in Pagu), i.e. to state one's intention indirectly to avoid hurting one's feeling. This politeness aspect is also reflected in the different sentence functions, i.e. mostly are affirmative, and the rest are contrastive, negative imperative, and interrogative. Note that none is positive imperative because of the same reason. Finally, we can speculate that in order to express politeness, proverbs must be 'thoughtful' (containing several predicates that modify certain objects). This is shown in the number of the clause, i.e. not too short and not too long (the most common one is with two clauses.

\section{CONCLUSION}

The main function of Pagu proverbs is to criticize others without hurting their feelings. Therefore, this study argues that the use of similes and metaphors which are the most common figurative types of Pagu proverbs is an instance of indirectness to express politeness (Brown \& Levinson, 1987; Thomas, 2014).

In addition, this study has shown three different features of Pagu proverbs that differ from European proverbs. First, the relationship between elements in Pagu proverbs discussed do not fit the two different relationships proposed by Dundes (1975). Secondly, the figurative language used in Pagu proverbs limits only simile and metaphor. Thirdly, the categorization of clause in Pagu is proverbs with nineteen samples. Table 6 summarizes the structure of Pagu proverbs in four different classifications. determined by its morphology, unlike that of European languages such as English and Dutch where any predicate (verb or adjective) whether in the main or sub clause must be attached by a pronoun prefix that refers to a subject.

The two different relationships between two descriptive elements, i.e. oppositional versus nonoppositional (Dundes, 1975) are not common in Pagu proverbs whereby only six, out of twenty-eight can be categorized as oppositional, and none is nonoppositional. The other relationship, namely topiccomment only fits one proverb in Pagu. The other twenty-one proverbs do not belong to any of these relationships that Dundes (1975) claims to be quite common in European proverbs.

The most common types of figurative language include simile with thirteen samples. The second most common one is metaphor with ten samples. Five other proverbs are distinctive in that they cannot be categorized into other types of figurative languages such as sarcasm, imagery, personification, symbolism, hyperbole, etc. (cfr. Carston \& Wearing, 2015).

The most common type of clause is affirmative with nineteen samples. Exclamatory and positive imperative hardly exist in Pagu. There are however two negative imperative sentences and five contrastive sentences. Interrogative is also rare as there are only two samples. The classification of the number of clauses is based on the Pagu morphological characteristics of the predicate.

Following such categorization, we have found that the most common ones are those with two clauses (fourteen samples), nine proverbs with one clause, two proverbs with three clauses, two proverbs with four clauses, and one proverb with five clauses. Finally, Pagu proverbs are not familiar among Pagu speakers themselves. This study may help document the proverbs and increase the speakers' pride to use and maintain their language. 


\section{REFERENCES}

Ahearn, L. M. (2011). Living language: An introduction to linguistic anthropology. in living language: An introduction to Linguistic anthropology. Wiley-Blackwell.

Angouri, J. (2010). Quantitative, qualitative or both? Combining methods in linguistic research. Research Methods in Linguistics, 1, 29-45.

Brown, P., \& Levinson, S. C. (1987). Politeness: Some universals in language usage. Cambridge University Press.

Carston, R., \& Wearing, C. (2015). Hyperbolic language and its relation to metaphor and irony. Journal of Pragmatics, 79, 79-92. https://doi.org/10.1016/j.pragma.2015.01.011

Citron, F., \& Zervos, E. A. (2018). A neuroimaging investigation into figurative language and aesthetic perception. In A. Baicchi, R. Digonnet \& J. Sanford (eds.), Sensory perceptions in language, embodiment and epistemology (pp. 77-94). Springer.

Cuddon, J. A. (2012). A dictionary of literary terms and literary theory. Wiley-Blackwell. DOI: $10.1002 / 9781444340563$

Dundes, A. (1975). On the structure of the proverb. Proverbium 25, 961-973.

Eaglestone, R. (2000). Doing English: A guide for literature students. Routledge.

Gibbs Jr, R. W., \& Colston, H. L. (2012). Interpreting figurative meaning. Cambridge University Press.

Glucksberg, S. (2008). Understanding figurative language: From metaphor to idioms. Oxford University Press. https://doi.org/10.1093/acprof:oso/9780195111 095.001.0001

Hisyam, M., Purwoko, D., Usman, \& D. PeranginAngin. (2012). Bahasa Pagu: Vitalitas dan pemertahanannya. PMB-LIPI.

Hisyam, M., Suganda, A., Usman, \& D. PeranginAngin. (2013). Pemertahanan Bahasa Pagu. LIPI Press.

Lauder, M. R. M. T. (2018). Obstacles to creating an inventory of languages in Indonesia: A dialectology perspective. In D.

Cunningham, D. E. Ingram, \& K. Sumbuk (eds.), Language diversity in The Pacific (pp. 40-53). Multilingual Matters. https://doi.org/10.21832/9781853598685-007

Mac Coinnigh, M. (2015). Structural aspects of proverbs. In H. Hrisztova-Gotthardt and M. A. Varga (eds.), Introduction to paremiology: A comprehensive guide to proverb studies (pp.112-132). De Gruyter. https://doi.org/10.2478/9783110410167.5

Manser, M. H. (2007). The facts on file dictionary of proverbs $\left(2^{\text {nd }}\right.$ ed.) (R. Fergusson \& D. Pickering, Eds.). Facts On File Inc.

Michael, I. (2014). The use of proverbial ideophones in Anaang, Southern Nigeria.
International Journal of Applied Linguistics and English Literature, 3(5), 72-81. https://doi.org/10.7575/aiac.ijalel.v.3n.5p.72

Mieder, W. (2006). The proof of the proverb is in the probing: Alan Dundes as pioneering paremiologist. Western Folklore, 65(3), 217262. https://doi.org/10.7592/fejf2007.35.mieder

Mieder, W. (2015). Origin of proverbs. In H. Hrisztova-Gotthardt and M. A. Varga (eds.), Introduction to paremiology: A comprehensive guide to proverb studies (pp.28-48). De Gruyter. https://doi.org/10.2478/9783110410167.2

Mieder, W., \& Mieder, W (2019). American proverbs and related sayings. In S. J. Bronner, The Oxford handbook of American folklore and folklife studies. Oxford University Press. https://doi.org/10.1093/oxfordhb/97801908406 17.013 .7

Njwe, E. (2015). “The palm oil with which words are eaten": Proverbs from Cameroon's endangered indigenous languages. In E. C. Zsiga, O. T. Boyer, \& R. Kramer (Eds.), Languages in Africa: Multilingualism, language policy, and education (pp. 118-126). Georgetown University Press.

Norrick, N. R. (2011). How proverbs mean: Semantic studies in English proverbs. DeGruyter.

Nowell, C. E. (2018). Magellan's voyage around the world: Three contemporary accounts. Pickle Partners Publishing.

Obadan, M. I. (2015). Language endangerment: Issues of Igbo proverbs. English Linguistics Research, 4(3). https://doi.org/10.5430/elr.v4n3p1

Onanuga, P. (2019). Proverbs, power and politics: A linguistic analysis of Osofisan's YungbaYungba and the dance contest. Language Matters, 50(2), 50-72. https://doi.org/10.1080/10228195.2019.157277 5

Payne, T. E. (2007). Describing morphosyntax: A guide for field linguists. Cambridge University Press.

Perangin-Angin, D. M. (2013). Meninjau struktur peribahasa Pagu: Sebuah bahasa di Indonesia Timur yang terancam punah. Jurnal Masyarakat dan Budaya, 15(3), 447-474.

Perangin-Angin, D. M. (2018). A descriptive grammar of the Pagu language. [Unpublished doctoral dissertation]. The University of Hong Kong.

Perangin-Angin, D. M. (2020). Two adjacent vowels in Pagu and their alternating word stress placement. International Journal of Humanity Studies, 3(2), 178-191. https://ejournal.usd.ac.id/index.php/IJHS/article/view/2 402 
Rasinger, S. M. (2010). Quantitative methods: Concepts, frameworks and issues. In L. Litosseliti (Ed.), Research methods in linguistics (pp. 49-67). Continuum International Publising Group.

Thomas, J. A. (2014). Meaning in interaction: An introduction to pracgmatics. Routledge.

Voorhoeve, C.L. (1984). Comparative linguistics and the West Papuan phylum. In E. K. M. Masinambow (ed.). Maluku dan Irian Jaya [Buletin LEKNAS Vol. III(1)]. LEKN/LIPI.

Voorhoeve, C. L. (1987). The non-Austronesian languages in the North Moluccas. In E. K. M. Masinambow (ed.). Maluku dan Irian Jaya [Buletin LEKNAS Vol. III(1)]. LEKN/LIPI.

Voorhoeve, C. L. (1988). The languages of the Northern Halmaheran stock. Papers in New Guinea Linguistics, no. 26., 181-209. (Pacific Linguistics A-76). Canberra: Australian National University.

$\begin{array}{ll}\text { List of abbreviation } \\ 1 & \text { first person } \\ 2 & \text { second person } \\ \text { third person } \\ 3 & \text { Benefactive } \\ \text { BEN } & \text { Causative } \\ \text { CAUSE } & \text { Direction away from speaker } \\ \text { DAS } & \text { English free translation } \\ \text { Eng } & \text { Exclusive } \\ \text { EX } & \text { Inclusive } \\ \text { IN } & \text { Literal meaning } \\ \text { Lit. } & \text { Local Malay } \\ \text { LM } & \text { Moral Message } \\ \text { Mes } & \text { Mutual } \\ \text { MUT } & \text { Negative } \\ \text { NEG } & \text { non-human } \\ \text { NH } & \text { non-related noun linker } \\ \text { NRNL } & \text { Object } \\ \text { O } & \text { Partial reduplication } \\ \text { PART. } & \text { plural } \\ \text { PL } & \text { Possessive } \\ \text { Poss } & \text { Reflective } \\ \text { REFL } & \text { related noun linked } \\ \text { RNL } & \text { Subject } \\ \text { S } & \text { Singular } \\ \text { SG } & \end{array}$

